\title{
Entrepreneurial attitude and entrepreneurial efficacy of technical secondary school students
}

\begin{abstract}
Entrepreneurial attitude and entrepreneurial efficacy are considered to be two important factors influencing studentsôintention and success in becoming entrepreneurs. This study was conducted to determine the entrepreneurial attitude and entrepreneurial efficacy of 3000 students following technical subjects in the secondary schools of Malaysia. The findings indicate that students scored high on entrepreneurial attitude components including selfesteem cognition, achievement cognition, and achievement affect. However, studentsômean score for entrepreneurial self-efficacy is moderate to high. This paper also discusses the importance of intervention programs and proper teaching and learning strategies to improve technical studentsôentrepreneurial attitude and self-efficacy.
\end{abstract}

Keyword: Entrepreneurial attitude; Entrepreneurial efficacy; Technical school students; Malaysia 